\title{
Hydrogen Production via Steam Reforming of Ethyl Alcohol over Palladium/Indium Oxide Catalyst
}

\author{
Tetsuo Umegaki, Yusuke Yamada, Atsushi Ueda, Nobuhiro Kuriyama, and Qiang Xu \\ National Institute of Advanced Industrial Science and Technology (AIST), 1-8-31 Midorigaoka, Ikeda, Osaka 563-8577, Japan \\ Correspondence should be addressed to Qiang Xu, q.xu@aist.go.jp
}

Received 17 March 2009; Accepted 3 July 2009

Recommended by Jim Anderson

\begin{abstract}
We report the synergetic effect between palladium and indium oxide on hydrogen production in the steam reforming reaction of ethyl alcohol. The palladium/indium oxide catalyst shows higher hydrogen production rate than indium oxide and palladium. Palladium/indium oxide affords ketonization of ethyl alcohol with negligible by-product carbon monoxide, while indium oxide mainly affords dehydration of ethyl alcohol, and palladium affords decomposition of ethyl alcohol with large amount of byproduct carbon monoxide. The catalytic feature of palladium/indium oxide can be ascribed to the formation of palladiumindium intermetallic component during the reaction as confirmed by X-ray diffraction and X-ray photoelectron spectroscopic measurements.
\end{abstract}

Copyright (C 2009 Tetsuo Umegaki et al. This is an open access article distributed under the Creative Commons Attribution License, which permits unrestricted use, distribution, and reproduction in any medium, provided the original work is properly cited.

\section{Introduction}

Hydrogen is a globally accepted clean fuel. Current methods for hydrogen production are mainly based on nonrenewable fossil fuels [1]. Renewable resources such as solar and biomass have attracted much attention as hydrogen resources to achieve the full environmental benefit for generating power with hydrogen fuel cells $[2,3]$. Ethyl alcohol is preferable as the hydrogen resources for the fuel cells compared with other resources since it can be easily produced from biomass by fermentation [4]. The most effective process for hydrogen production from ethyl alcohol is the steam reforming reaction, $\mathrm{C}_{2} \mathrm{H}_{5} \mathrm{OH}+3 \mathrm{H}_{2} \mathrm{O} \rightarrow 6 \mathrm{H}_{2}+2 \mathrm{CO}_{2}$. For this reaction, Cobalt-[5, 6], Nickel-[7], or Rhodium[8] based catalysts exhibited high activities. In the previous literature, catalysts capable of converting ethyl alcohol to carbon dioxide and hydrogen without carbon monoxide formation have been reported but they need high temperatures (> $623 \mathrm{~K}$ ) or show low-hydrogen production rates. Carbon monoxide is a by-product, which should be removed to prevent from the poisoning of electrode catalysts of fuel cells. On the other hand, we have reported that simple indium oxides exhibit high activities for hydrogen production from ethyl alcohol via the following reaction, $2 \mathrm{C}_{2} \mathrm{H}_{5} \mathrm{OH}+\mathrm{H}_{2} \mathrm{O} \rightarrow$
$4 \mathrm{H}_{2}+\mathrm{CO}_{2}+\mathrm{CH}_{3} \mathrm{COCH}_{3}$ at $623 \mathrm{~K}$ [9]. Over the indium oxide catalysts, hydrogen is generated without detectable carbon monoxide contamination, while hydrogen production rate is low below $623 \mathrm{~K}$. Otherwise, it has been reported that decomposition of ethyl alcohol to hydrogen accompanied by the formation of carbon monoxide and methane mainly occurs over supported palladium catalyst, while the supports greatly affect the product distribution over palladium catalysts $[10,11]$. The effects of support oxides on product selectivity over palladium catalysts have been reported in reactions such as dehydrogenation of ethyl alcohol [12] and steam reforming of methyl alcohol [13]. The specific interaction of palladium with a certain metal oxides leads to high activity for hydrogen production from ethyl alcohol.

Herein, we present the results of the synergetic effect between palladium and indium oxide on hydrogen production in the steam reforming reaction of ethyl alcohol.

\section{Experimental}

2.1. Catalyst Preparation. The $\mathrm{Pd} / \mathrm{In}_{2} \mathrm{O}_{3}$ catalysts with $\mathrm{Pd}$ contents of $0.2-10.0 \mathrm{wt} . \%$ were prepared by impregnation method using $0.1 \mathrm{M}$ aqueous solution of $\mathrm{Pd}\left(\mathrm{NO}_{3}\right)_{2} \cdot \mathrm{nH}_{2} \mathrm{O}$ 
TABLE 1: Conversion and product distribution for the reaction of ethyl alcohol and steam over various catalys t. ${ }^{\mathrm{a}}$

\begin{tabular}{lccccccccc}
\hline Catalyst & \multicolumn{1}{c}{ Conversion (\%) } & & \multicolumn{5}{c}{ Composition (\%) } \\
& & $\mathrm{H}_{2}$ & $\mathrm{CO}$ & $\mathrm{CO}_{2}$ & $\mathrm{CH}_{4}$ & $\mathrm{C}_{2} \mathrm{H}_{4}$ & $\mathrm{C}_{3} \mathrm{H}_{6}$ & $\mathrm{CH}_{3} \mathrm{CHO}^{2}$ & $\mathrm{CH}_{3} \mathrm{COCH}_{3}$ \\
\hline $\mathrm{Pd}$ & 95.4 & 34.9 & 33.3 & - & 31.2 & - & - & 0.7 & - \\
$\mathrm{In}_{2} \mathrm{O}_{3}$ & 79.2 & 21.7 & - & 4.1 & - & 59.1 & 0.6 & 6.2 & 8.3 \\
$\mathrm{Pd} / \mathrm{In}_{2} \mathrm{O}_{3}{ }^{\mathrm{c}}$ & 97.8 & 62.1 & - & 12.3 & - & 0.9 & - & 2.9 & 21.8 \\
\hline
\end{tabular}

${ }^{a}$ Reaction conditions: $\mathrm{C}_{2} \mathrm{H}_{5} \mathrm{OH}: \mathrm{H}_{2} \mathrm{O}: \mathrm{N}_{2}=0.5: 2.0: 97.5$ (molar ratio), $\mathrm{N}_{2}$ flow rate $=50 \mathrm{~mL}^{-1}$, reaction time $=10 \mathrm{~h}$, reaction temperature $=$ $573 \mathrm{~K}$.

${ }^{\mathrm{b}}$ Molar percentage of products (water not included).

${ }^{\mathrm{c}} \mathrm{Pd}$ loading of $\mathrm{Pd} / \mathrm{In}_{2} \mathrm{O}_{3}=5.0$ wt. $\%$

(Kishida Chem. Co.) and commercial $\mathrm{In}_{2} \mathrm{O}_{3}$ (Mitsuwa Chem. Co.). The commercial $\mathrm{In}_{2} \mathrm{O}_{3}$ was immersed in the aqueous $\mathrm{Pd}\left(\mathrm{NO}_{3}\right)_{2}$ solution and was dried with a rotating evaporator at $343 \mathrm{~K}$. The sample was calcined in air at $623 \mathrm{~K}$ for $3 \mathrm{~h}$. The specific surface area of $\mathrm{In}_{2} \mathrm{O}_{3}$ catalyst is $7 \mathrm{~m}^{2} \mathrm{~g}^{-1}$, and the specific surface area of $5.0 \mathrm{wt} . \% \mathrm{Pd} / \mathrm{In}_{2} \mathrm{O}_{3}$ catalyst is $10 \mathrm{~m}^{2} \mathrm{~g}^{-1}$. Unsupported Pd catalyst was prepared by thermal decomposition of $\mathrm{Pd}\left(\mathrm{NO}_{3}\right)_{2} \cdot \mathrm{nH}_{2} \mathrm{O}$ in air at $623 \mathrm{~K}$ for $3 \mathrm{~h}$. All the catalysts have been used without reduction pretreatment before the reaction.

2.2. Characterization of Catalysts. Powder XRD measurements were performed on a RINT2200 diffractometer (Rigaku) equipped with a $\mathrm{Cu} \mathrm{K} \alpha \mathrm{X}$-ray tube operating at $40 \mathrm{kV}$ and $40 \mathrm{~mA}$. X-ray photoelectron spectra (XPS) were acquired with an ESCA-3400 spectrometer (Shimadzu) equipped with an $\mathrm{Mg} \mathrm{K} \alpha \mathrm{X}$-ray exciting source $(1253.6 \mathrm{eV})$ operating at $10 \mathrm{kV}$ and $10 \mathrm{~mA}$. The binding energies (BE) were referred to the $\mathrm{C} 1 \mathrm{~s}$ peak at $285.0 \mathrm{eV}$.

2.3. Evaluation of Catalytic Performance. The catalysts $(65 \mathrm{mg})$ held in L-shaped quartz tubes were loaded in a fixed-bed flow reactor (TPR-5D, Bell Japan Inc.). The premixed solution of water and ethyl alcohol was fed by a syringe pump (KD Science) to a vaporizer heated at $403 \mathrm{~K}$, through which an $\mathrm{N}_{2}$ stream was passed. A flow of $0.5 \% \mathrm{C}_{2} \mathrm{H}_{5} \mathrm{OH} / 2.0 \% \mathrm{H}_{2} \mathrm{O}$ in $\mathrm{N}_{2}$ stream (molar ratio) was introduced into the reactor with a rate of $50 \mathrm{~mL}$ $\min ^{-1}$ at $573 \mathrm{~K}$. Effluent gas was analyzed by two online microgas chromatographs, GC3000A and M-200H (Agilent), equipped with TC detectors. GC3000A is equipped with Porapak $Q$ using $\mathrm{He}$ as the carrier gas for separating $\mathrm{CO}_{2}, \mathrm{C}_{2} \mathrm{H}_{4}, \mathrm{C}_{2} \mathrm{H}_{6}, \mathrm{C}_{3} \mathrm{H}_{6}, \mathrm{CH}_{3} \mathrm{CHO}$, and $\mathrm{C}_{2} \mathrm{H}_{5} \mathrm{OH}$ and Molecular Sieve $5 \mathrm{~A}$ using $\mathrm{Ar}$ as the carrier gas for separating $\mathrm{H}_{2}, \mathrm{CO}$, and $\mathrm{CH}_{4} . \mathrm{M}-200 \mathrm{H}$ is equipped with Porapak $Q$ using $\mathrm{He}$ as the carrier gas for separating $\mathrm{C}_{2} \mathrm{H}_{4}, \mathrm{C}_{2} \mathrm{H}_{6}, \mathrm{C}_{3} \mathrm{H}_{6}$, $\mathrm{CH}_{3} \mathrm{CHO}, \mathrm{C}_{2} \mathrm{H}_{5} \mathrm{OH}$, and $\mathrm{CH}_{3} \mathrm{COCH}_{3}$ and Molecular Sieve $5 \mathrm{~A}$ using $\mathrm{He}$ as the carrier gas for separating $\mathrm{CO}$ and $\mathrm{CH}_{4}$. The detection limit of $\mathrm{CO}$ is $<50 \mathrm{ppm}$.

\section{Results and Discussion}

Table 1 shows the conversion and product distribution over $\mathrm{Pd}, \mathrm{In}_{2} \mathrm{O}_{3}$, and $\mathrm{Pd} / \mathrm{In}_{2} \mathrm{O}_{3}$, catalysts at $573 \mathrm{~K}$ in the condition for steam reforming of ethyl alcohol. The table lists the conversion of ethyl alcohol and the molar composition of the products. All the catalysts show conversions of ethyl alcohol higher than $77 \%$, while the composition of hydrogen depends on the catalyst. The Pd catalyst gives rise to the formation of hydrogen, carbon monoxide, and methane as the main products, indicating that Pd is highly active for decomposition of ethyl alcohol through the dehydrogenation step to acetaldehyde as follows [11]

$$
\mathrm{C}_{2} \mathrm{H}_{5} \mathrm{OH} \longrightarrow \mathrm{H}_{2}+\mathrm{CH}_{3} \mathrm{CHO} \longrightarrow \mathrm{H}_{2}+\mathrm{CO}+\mathrm{CH}_{4} .
$$

$\mathrm{In}_{2} \mathrm{O}_{3}$ catalyst shows the lowest composition of hydrogen with ethene as the main product, indicating that $\operatorname{In}_{2} \mathrm{O}_{3}$ is highly active for dehydration of ethyl alcohol as follows:

$$
\mathrm{C}_{2} \mathrm{H}_{5} \mathrm{OH} \rightarrow \mathrm{C}_{2} \mathrm{H}_{4}+\mathrm{H}_{2} \mathrm{O} \text {. }
$$

This reaction is known to proceed over acidic catalysts [14]. By combining Pd on $\operatorname{In}_{2} \mathrm{O}_{3}$, we observed a significant increase in hydrogen yield. As 2-propanone and carbon dioxide are also produced in this reaction, the $\mathrm{Pd} / \mathrm{In}_{2} \mathrm{O}_{3}$ catalyst is highly selective for ketonization of ethyl alcohol with acetaldehyde as the reaction intermediate as follows [9]:

$$
\begin{array}{r}
\mathrm{C}_{2} \mathrm{H}_{5} \mathrm{OH} \longrightarrow \mathrm{H}_{2}+\mathrm{CH}_{3} \mathrm{CHO} \stackrel{\rightarrow+1 / 2 \mathrm{H}_{2} \mathrm{O}}{\longrightarrow} \\
2 \mathrm{H}_{2}+\frac{1}{2} \mathrm{CH}_{3} \mathrm{COCH}_{3}+\frac{1}{2} \mathrm{CO}_{2} .
\end{array}
$$

According to (3), the steam reforming of ethyl alcohol gives the products with the molar ratio of $\mathrm{H}: \mathrm{C}: \mathrm{O}=7.2: 2.0$ : 1.5 .

Another route to the formation of 2-propanone is as follows;

$$
\begin{aligned}
\mathrm{C}_{2} \mathrm{H}_{5} \mathrm{OH} & \longrightarrow \mathrm{H}_{2}+\mathrm{CH}_{3} \mathrm{CHO} \longrightarrow \frac{3}{5} \mathrm{CH}_{3} \mathrm{COCH}_{3} \\
& +\frac{1}{5} \mathrm{CO}_{2}+\frac{6}{5} \mathrm{H}_{2} .
\end{aligned}
$$

No steam is consumed in this reaction, which gives the products with the molar ratio of $\mathrm{H}: \mathrm{C}: \mathrm{O}=6.0: 2.0: 1.0$.

The observed molar ratio of $\mathrm{H}: \mathrm{C}: \mathrm{O}$ over the $5.0 \mathrm{wt} . \%$ $\mathrm{Pd} / \mathrm{In}_{2} \mathrm{O}_{3}$ catalyst is $6.5: 2.0: 1.2$ (Table 1 ), suggesting that $0.20 \mathrm{~mol}$ of $\mathrm{H}_{2} \mathrm{O}$ per converted ethyl alcohol is consumed. Moreover, no CO impurity was detected within the detection limit ( $<50 \mathrm{ppm}$ ) over the catalyst, and no deactivation was observed for the catalyst during the reaction for $10 \mathrm{~h}$.

Figure 1 depicts XRD profiles of the $\mathrm{Pd} / \mathrm{In}_{2} \mathrm{O}_{3}$ catalysts with $0.2,1.0$, and 5.0 wt. $\%$ Pd before and after the reaction. 
TABLE 2: Effect of Pd loading on conversion and product distribution for the reaction of ethyl alcohol and steam over $\mathrm{Pd} / \mathrm{In}_{2} \mathrm{O}_{3}{ }^{a}$

\begin{tabular}{|c|c|c|c|c|c|c|c|c|c|}
\hline \multirow[t]{2}{*}{ Pd (wt.\%) } & \multirow[t]{2}{*}{ Conversion $(\%)$} & \multicolumn{8}{|c|}{ Composition $(\%)^{\mathrm{b}}$} \\
\hline & & $\mathrm{H}_{2}$ & $\mathrm{CO}$ & $\mathrm{CO}_{2}$ & $\mathrm{CH}_{4}$ & $\mathrm{C}_{2} \mathrm{H}_{4}$ & $\mathrm{C}_{3} \mathrm{H}_{6}$ & $\mathrm{CH}_{3} \mathrm{CHO}$ & $\mathrm{CH}_{3} \mathrm{COCH}_{3}$ \\
\hline 0 & 79.2 & 21.7 & - & 4.1 & - & 59.1 & 0.6 & 6.2 & 8.3 \\
\hline 0.2 & 77.8 & 53.0 & - & 5.3 & - & 10.8 & - & 21.1 & 9.8 \\
\hline 1.0 & 93.7 & 59.9 & - & 12.1 & - & 2.3 & - & 5.1 & 20.6 \\
\hline 5.0 & 97.8 & 62.1 & - & 12.3 & - & 0.9 & - & 2.9 & 21.8 \\
\hline 10.0 & 99.9 & 60.1 & - & 14.2 & - & - & 0.1 & 1.9 & 23.7 \\
\hline
\end{tabular}


${ }^{\mathrm{b}}$ Molar percentage of products (water not included).

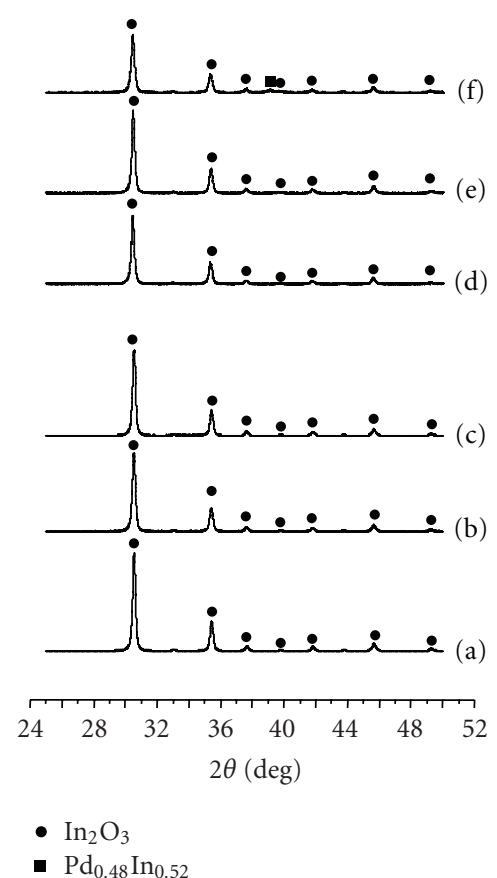

Figure 1: Powder X-ray diffraction patterns for the $\mathrm{Pd} / \mathrm{In}_{2} \mathrm{O}_{3}$ catalysts before reaction with (a) $0.2 \mathrm{wt} . \%$, (b) $1.0 \mathrm{wt} . \%$, and (c) 5.0 wt.\% Pd and after reaction at $573 \mathrm{~K}$ with (d) $0.2 \mathrm{wt} . \%$, (e) 1.0 wt. $\%$, and (f) 5.0 wt.\% Pd.

Only the peaks ascribed to $\mathrm{In}_{2} \mathrm{O}_{3}$ phases appear at $2 \theta=30.5$, $35.4,37.7,39.8$, 45.7, and 49.3 (JCPDS: 6-0416) in the profile for all the catalysts before reaction. A new small peak appears at $2 \theta=39.1^{\circ}$ for the $\mathrm{Pd} / \mathrm{In}_{2} \mathrm{O}_{3}$ catalyst with $5.0 \mathrm{wt} . \% \mathrm{Pd}$ after reaction, which can be ascribed to $\mathrm{Pd}_{0.48} \operatorname{In}_{0.52}$ (JCPDS: 46-1011) $[15,16]$. The result indicates that $\operatorname{Pd}_{0.48} \operatorname{In}_{0.52}$ intermetallic species is formed in the $\mathrm{Pd} / \mathrm{In}_{2} \mathrm{O}_{3}$ catalyst during the reaction of ethyl alcohol, which might be the active phase for ketonization of ethyl alcohol.

Figure 2 represents the XPS spectra in Pd 3d region (left) in the $\mathrm{Pd} / \mathrm{In}_{2} \mathrm{O}_{3}$ catalysts before and after the reaction. The peak intensities of $\mathrm{Pd} 3 \mathrm{~d}$ spectra for the $\mathrm{Pd} / \mathrm{In}_{2} \mathrm{O}_{3}$ catalysts with $0.2,1.0$, and $5.0 \mathrm{wt} . \% \mathrm{Pd}$ before reaction increase with increase in Pd loading. All the spectra of the catalyst before reaction exhibit a $\mathrm{Pd} 3 \mathrm{~d}_{5 / 2}$ band at $336.9 \mathrm{eV}$, which can be associated with oxidized surface $\mathrm{Pd}$ species [16]. The intensity of $\mathrm{Pd} 3 \mathrm{~d}$ lines for 0.2 and 1.0 wt. $\% \mathrm{Pd} / \mathrm{In}_{2} \mathrm{O}_{3}$ catalyst

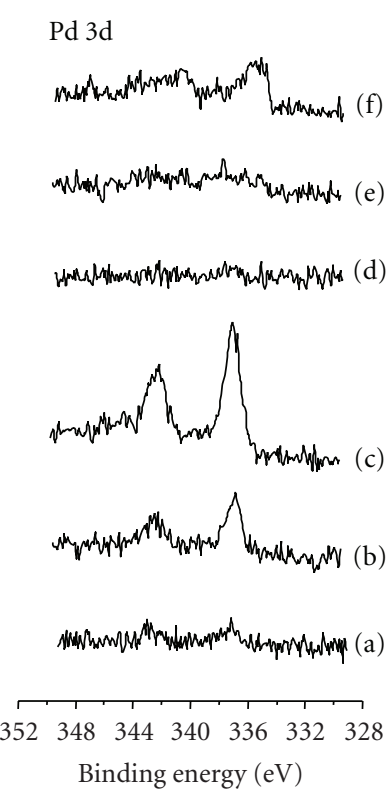

(a)
In $3 \mathrm{~d}$

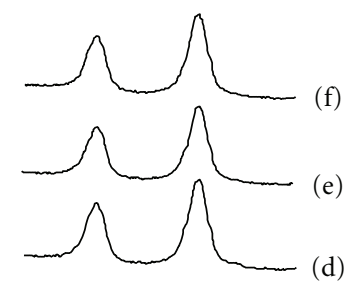

(d)

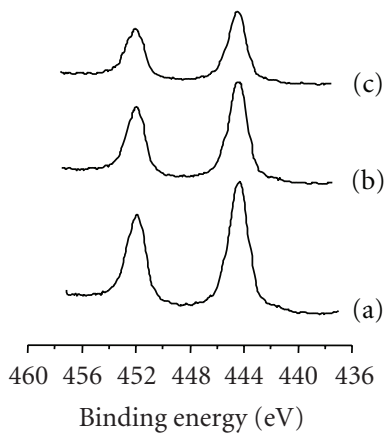

(b)
FIGURE 2: X-ray photoelectron spectra in the Pd 3d (left) and the In $3 \mathrm{~d}$ (right) region for the $\mathrm{Pd} / \mathrm{In}_{2} \mathrm{O}_{3}$ catalysts before reaction with (a) $0.2 \mathrm{wt} . \%$, (b) $1.0 \mathrm{wt} . \%$, and (c) $5.0 \mathrm{wt} . \% \mathrm{Pd}$ and after reaction at $573 \mathrm{~K}$ with (d) $0.2 \mathrm{wt} . \%$, (e) 1.0 wt.\%, and (f) 5.0 wt.\% Pd.

after reaction is too small to identify the peaks of $\mathrm{Pd} 3 \mathrm{~d}$ spectra, whereas the spectrum of the $5.0 \mathrm{wt} . \% \mathrm{Pd} / \mathrm{In}_{2} \mathrm{O}_{3}$ catalyst exhibits a $\mathrm{Pd} 3 \mathrm{~d}_{5 / 2}$ band at $335.4 \mathrm{eV}$. This peak is slightly shifted from the peak position associated with metallic $\mathrm{Pd}(335.0 \mathrm{eV})[15,16]$, suggesting the formation of Pd-In intermetallic species during the reaction of ethyl alcohol and steam $[15,16]$. All the XPS spectra in In $3 d$ region in the $\mathrm{Pd} / \mathrm{In}_{2} \mathrm{O}_{3}$ catalysts before and after the reaction exhibit In $3 \mathrm{~d}_{5 / 2}$ bands at $444.4-444.5 \mathrm{eV}$ (Figure 1, right). The bands can be associated with oxidized surface $\mathrm{In}^{3+}$ species [17]. A small $\mathrm{In}^{0}$ peak (443.7 eV [15]) for the Pd-In intermetallic species observed in the XRD measurement may be overlapped by the broad $\mathrm{In}^{3+}$ peak at around $444.5 \mathrm{eV}$.

As shown in Table 1, in the case of Pd catalyst without $\mathrm{In}_{2} \mathrm{O}_{3}$ support, the decomposition of the acetaldehyde intermediate rapidly decarbonylated to carbon monoxide and methane (1), whereas for the $\mathrm{Pd} / \mathrm{In}_{2} \mathrm{O}_{3}$ catalyst the 
acetaldehyde intermediate, which may be stabilized by the $\mathrm{Pd}_{0.48} \mathrm{In}_{0.52}$ species [12], gives 2-propanone and carbon dioxide with hydrogen product via ketonization (3).

Table 2 shows the effect of Pd loading on the activity of $\mathrm{Pd} / \mathrm{In}_{2} \mathrm{O}_{3}$ catalyst for the reaction of ethyl alcohol and steam. All the catalysts show conversions of ethyl alcohol at the same levels, while the composition of hydrogen depends on the $\mathrm{Pd}$ loading. $\mathrm{In}_{2} \mathrm{O}_{3}$ mainly affords the dehydrate product, $\mathrm{C}_{2} \mathrm{H}_{4}$, (2) with production of small amount of hydrogen. With increasing the loading from 0 to $0.2 \mathrm{wt} . \%$, the composition is significantly increased. The dehydrate product, $\mathrm{C}_{2} \mathrm{H}_{4}$, is drastically decreased from $59.1 \%$ to $9.8 \%$, while acetaldehyde is increased from $6.2 \%$ to $21.1 \%$ ((3), first step). Further increase of Pd loading from 0.2 to $1.0-10.0 \mathrm{wt}$. $\%$ gives rise to the increase of 2-propanone, carbon dioxide, and hydrogen ((3), second step) as the compensation of acetaldehyde.

\section{Conclusions}

We have investigated the synergetic effect between palladium and indium oxide on hydrogen production in the steam reforming reaction of ethyl alcohol. Palladium/indium oxide catalyst is highly active for ketonization of ethyl alcohol with high composition of hydrogen and negligible byproduct carbon monoxide, while indium oxide is highly active for dehydration of ethyl alcohol with low composition of hydrogen, and palladium is highly active for decomposition of ethyl alcohol with large amount of by-product carbon monoxide. No deactivation was observed for the palladium/indium oxide catalyst during the reaction for 10 h. The results of XRD and XPS measurement suggest that palladium-indium intermetallic species is formed during the reaction as the active phase for the reaction. The intermetallic species stabilizes acetaldehyde intermediate and promotes ketonization of the intermediate to hydrogen, 2-propanone, and carbon dioxide.

\section{References}

[1] J. R. Rostrup-Nielsen, "Fuels and energy for the future: the role of catalysis," Catalysis Reviews, vol. 46, no. 3-4, pp. 247-270, 2004.

[2] M. Grätzel, "Photoelectrochemical cells," Nature, vol. 414, no. 3, pp. 338-344, 2001.

[3] R. R. Davda, J. W. Shabaker, G. W. Huber, R. D. Cortright, and J. A. Dumesic, "A review of catalytic issues and process conditions for renewable hydrogen and alkanes by aqueousphase reforming of oxygenated hydrocarbons over supported metal catalysts," Applied Catalysis B, vol. 56, no. 1-2, pp. 171186, 2005.

[4] G. A. Deluga, J. R. Salge, L. D. Schmidt, and X. E. Verykios, "Renewable hydrogen from ethanol by autothermal reforming," Science, vol. 303, no. 5660, pp. 993-997, 2004.

[5] F. Haga, T. Nakajima, H. Miya, and S. Mishima, "Catalytic properties of supported cobalt catalysts for steam reforming of ethanol," Catalysis Letters, vol. 48, no. 3-4, pp. 223-227, 1997.

[6] J. Llorca, P. R. de la Piscina, J.-A. Dalmon, J. Sales, and N. Homs, "Co-free hydrogen from steam-reforming of bioethanol over $\mathrm{ZnO}$-supported cobalt catalysts: effect of the metallic precursor," Applied Catalysis B, vol. 43, no. 4, pp. 355369, 2003.

[7] A. N. Fatsikostas and X. E. Verykios, "Reaction network of steam reforming of ethanol over Ni-based catalysts," Journal of Catalysis, vol. 225, no. 2, pp. 439-452, 2004.

[8] C. Diagne, H. Idriss, and A. Kiennemann, "Hydrogen production by ethanol reforming over $\mathrm{Rh} / \mathrm{CeO}_{2}-\mathrm{ZrO}_{2}$ catalysts," Catalysis Communications, vol. 3, no. 12, pp. 565-571, 2002.

[9] T. Umegaki, K. Kuratani, Y. Yamada, et al., "Hydrogen production via steam reforming of ethyl alcohol over nanostructured indium oxide catalysts," Journal of Power Sources, vol. 179, no. 2, pp. 566-570, 2008.

[10] J. P. Breen, R. Burch, and H. M. Coleman, "Metal-catalysed steam reforming of ethanol in the production of hydrogen for fuel cell applications," Applied Catalysis B, vol. 39, no. 1, pp. 65-74, 2002.

[11] A. Casanovas, J. Llorca, N. Homs, J. L. G. Fierro, and P. R. de la Piscina, "Ethanol reforming processes over $\mathrm{ZnO}$-supported palladium catalysts: effect of alloy formation," Journal of Molecular Catalysis A, vol. 250, no. 1-2, pp. 44-49, 2006.

[12] N. Iwasa, O. Yamamoto, R. Tamura, M. Nishikubo, and N. Takezawa, "Difference in the reactivity of acetaldehyde intermediates in the dehydrogenation of ethanol over supported Pd catalysts," Catalysis Letters, vol. 62, no. 2-4, pp. 179-184, 1999.

[13] N. Iwasa, W. Nomura, T. Mayanagi, S.-I. Fujita, M. Arai, and N. Takezawa, "Hydrogen production by steam reforming of methanol," Journal of Chemical Engineering of Japan, vol. 37, no. 2, pp. 286-293, 2004.

[14] J. Llorca, P. R. de la Piscina, J. Sales, and N. Homs, "Direct production of hydrogen from ethanolic aqueous solutions over oxide catalysts," Chemical Communications, no. 7, pp. 641-642, 2001.

[15] T. Hirano, Y. Ozawa, T. Sekido, T. Ogino, T. Miyao, and S. Naito, "The role of additives in the catalytic reduction of $\mathrm{NO}$ by $\mathrm{CO}$ over $\mathrm{Pd}-\mathrm{In} / \mathrm{SiO}_{2}$ and $\mathrm{Pd}-\mathrm{Pb} / \mathrm{SiO}_{2}$ catalysts," Applied Catalysis A, vol. 320, pp. 91-97, 2007.

[16] F. A. Marchesini, S. Irusta, C. Querini, and E. Miró, "Spectroscopic and catalytic characterization of Pd-In and Pt-In supported on $\mathrm{Al}_{2} \mathrm{O}_{3}$ and $\mathrm{SiO}_{2}$, active catalysts for nitrate hydrogenation," Applied Catalysis A, vol. 348, no. 1, pp. 60-70, 2008.

[17] T. L. Barr and Y. L. Liu, "An X-ray photoelectron spectroscopy study of the valence band structure of indium oxides," Journal of Physics and Chemistry of Solids, vol. 50, no. 7, pp. 657-664, 1989. 


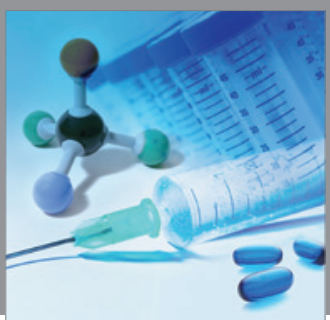

International Journal of

Medicinal Chemistry

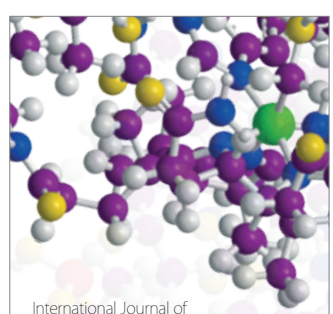

Carbohydrate Chemistry

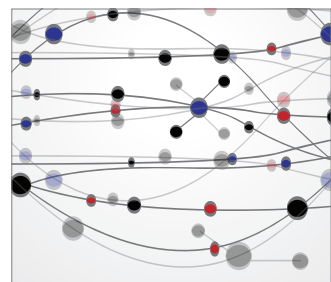

The Scientific World Journal
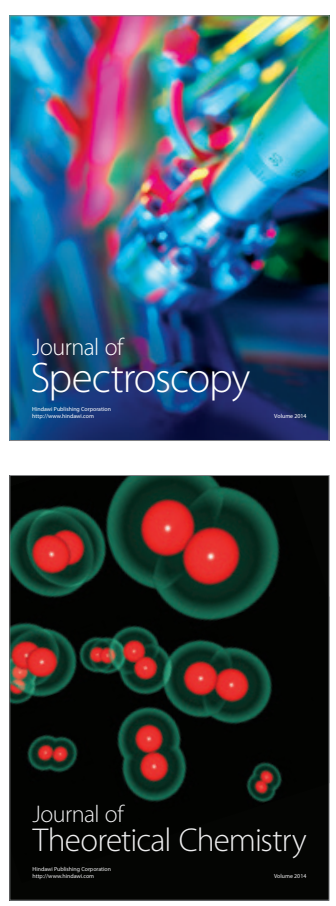
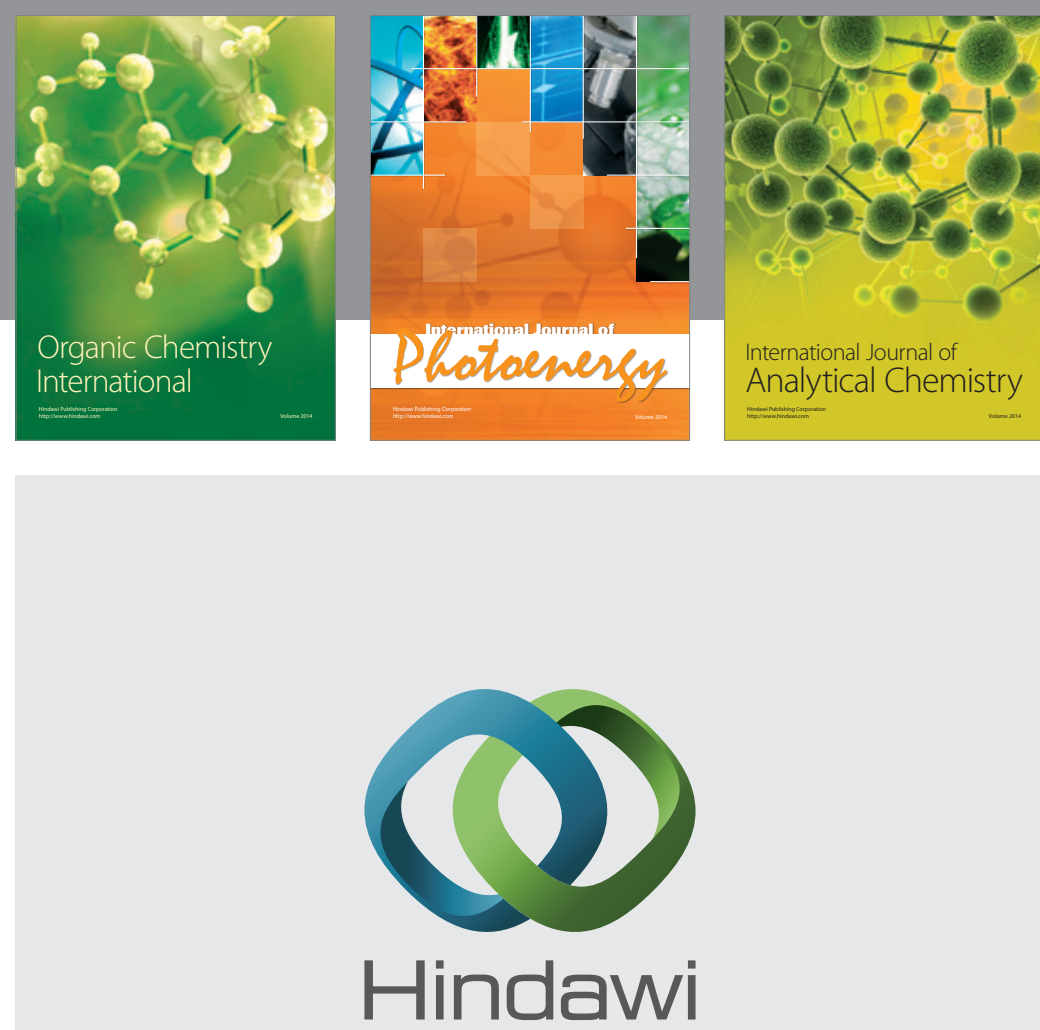

Submit your manuscripts at

http://www.hindawi.com
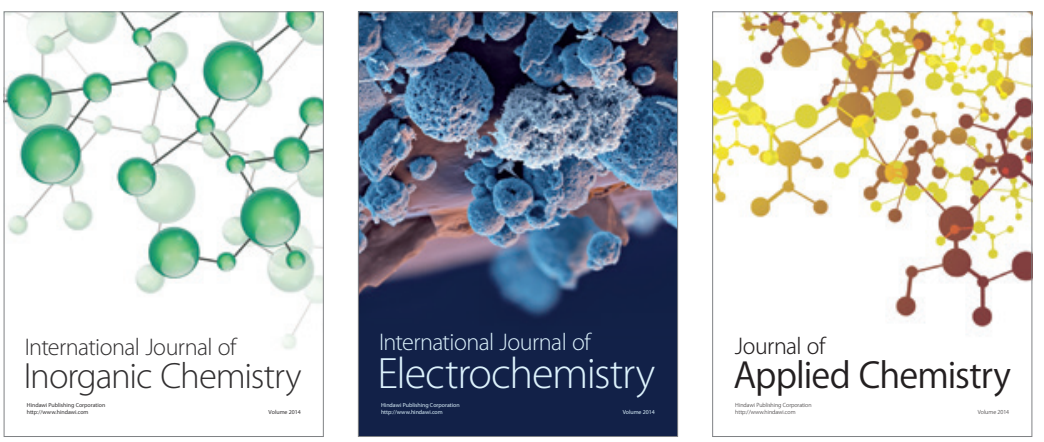

Journal of

Applied Chemistry
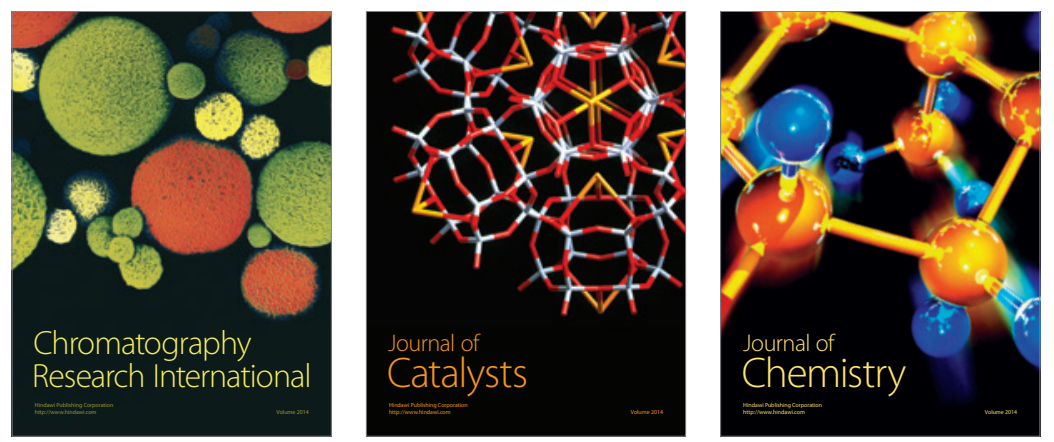
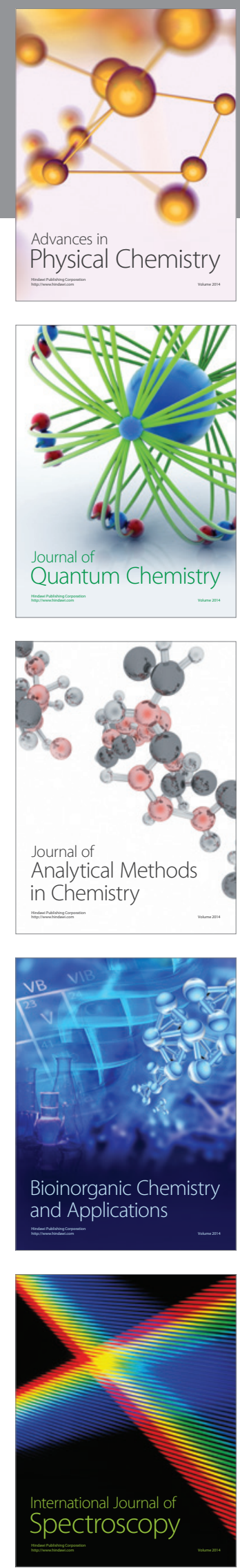